\title{
BODY-MASS ESTIMATION FROM MIDDLE PLEISTOCENE FALLOW DEER OF EUROPE
}

\author{
Dario Stefanelli1 ${ }^{1}$ \& \& Beniamino Mecozzi² \\ ${ }^{1}$ Dipartimento di Biologia, Università degli Studi di Bari Aldo Moro, via Orabona 4, 70125, Bari, Italy; \\ ${ }^{2}$ PaleoFactory Laboratory, Department of Earth Science, Sapienza, University of Rome, P.le Aldo Moro 5, 00185, Rome, Italy.
}

\section{KEYWORDS: \\ Dama; \\ Galerian; \\ size variability; \\ cervid.}

\section{Bullet-Points Abstract \\ - Analysis of a sample covering a period of time ranging from 700,000 to 250,000 years ago. \\ - Body mass comparison between fallow deer species of the Middle Pleistocene. \\ - Comparison of the overall averages obtained for each site considered. \\ - Considerations on the correlation between size variability and climatic situation.}

\section{INTRODUCTION}

The size variability in the mammals is considered by many scholars an important tool to investigate their response to climatic changes (among others Lister et al., 2010; Van Asperen et al., 2012; Mecozzi \& Bartolini Lucenti, 2018). Moreover, fluctuations in size or reduction trend in mammals represents a great tool for the biochronology (e.g., Van Asperen, 2010; Brugual \& Boudadi-Maligne, 2011). Ecological factors that can influence the body size of mammals include climate (mainly mean annual temperature and seasonality), population density and interspecific competition (Geist, 1971; 1987; Lindstedt \& Boyce, 1985; Weinstock, 1997). These factors tend to induce the increase of the body size in populations inhabiting region affected by cold conditions (Weinstock, 1997). Particularly, climate can produce demographic effects on the populations. In fact, more severe winters, for example, cause a strong decrease of the food supply and lead to a higher mortality rate (Weinstock, 1997). As a consequence, during the following growth season the intraspecific competition decreases (Guthrie, 1984). The reductions of competition in turn, led a higher quality and quantity of food resources, giving rise the development of a larger body size (Weinstock, 1997). Considering this, the relation between body size and climatic conditions appears to be valid, which leads the large size during the glacial stage and the small size during the interglacial one.

Among cervids, a preliminary analysis of Cervus elaphus Linnaeus, 1758 samples from Late Pleistocene Italian sites was conducted by Di Stefano et al. (2015). The authors stated that the sample from MIS 2 (Marine Isotope Stage) of the northern Italy was of a large size, larger than the contemporaneous ones from central and southern Italy and from early interglacial and glacial stages (MIS 5-3). Larger body proportions in glacial specimens was also recognized from Steele (2002), who also documented the smallest size in the sample referred to MIS 5. Nevertheless different results were reported by Van der Made et al. (2014) for a large dataset from Middle to Late Pleistocene European sites. His results showthat samples from interglacials were larger than glacial ones, and, in addition, the samples from MIS 7 are larger in size than earlier (MIS 9) and later (MIS 5) ones.

Today the genus Dama is composed by two species: Dama dama Linnaeus, 1758 and Dama mesopotamica Brooke, 1875. The extant Dama dama is widespread in the western Palearctic, whereas in the Middle East $D$. mesopotamica occurs. The fallow deer is a highly plastic species, inhabiting a wide range of habitats, including forest, scrubland and grassland (Masseti \& Mertzanidou, 2008) . Based on the features of the antler of the fossil specimens from the Middle Pleistocene of Europe, several species of fallow deer have been proposed. Recently, Dama roberti Breda \& Lister, 2013, a new species of palmated fallow deer, was described by Breda \& Lister (2013). This taxon possesses distinct antler morphology, with a narrow palmation ending in a single terminal point very different from later species, Dama clactoniana Falconer, 1868 and extant $D$. dama, which display a strongly palmated antlers and a second tine (sometimes also a third tine in D. clactoniana) above the basal one. In the European fossil record, the Clacton fallow deer occurs in the late Middle Pleistocene (Fontana Ranuccio Faunal Unit, $0.458 \mathrm{Ma}$ ), and their remains were recognized in Britain, Italy, France and Spain (Breda et al., 2015; Strani et al., 2018). 


\begin{tabular}{|c|c|c|c|c|c|}
\hline Species & Site & MIS & Reference & $M^{2}$ & $\mathbf{M}_{2}$ \\
\hline Dama roberti & Pakefield & MIS 17 & (Stuart \& Lister, 2010) & 57.7 & $\begin{array}{c}65.1 \\
(\max =67.1-\min =63.1 ; n=2)\end{array}$ \\
\hline Dama roberti & West Runton & MIS $17-15$ & (Stuart \& Lister, 2010) & 55.0 & $\begin{array}{c}55.7 \\
(\max =59.4-\min =53.3 ; n=8)\end{array}$ \\
\hline Dama roberti & Soleilhac & MIS $17-15$ & (Lacombat, 2005) & & $\begin{array}{c}53.3 \\
(\max =57.6-\min =49.3 ; n=4)\end{array}$ \\
\hline Dama cf. roberti & Isernia La Pineta & MIS 15 & (Strani et al., 2018) & 59.5 & 60.9 \\
\hline Dama roberti & Valdemino & MIS 14 & (Breda, 2015) & & 58.8 \\
\hline Dama cf. roberti & $\begin{array}{l}\text { Contrada } \\
\text { Monticelli }\end{array}$ & MIS $15-13$ & (Mecozzi et al.2017; Stefanelli et al. 2019) & $\begin{array}{c}64.1 \\
(\max =64.1-\min =64.1 ; n=2)\end{array}$ & $\begin{array}{c}51.7 \\
(\max =53.3-\min =49.3 ; n=3)\end{array}$ \\
\hline Dama clactoniana & Fontana Ranuccio & MIS 12 & (Biddittu et al., 1979; Segre \& Ascenzi, 1984) & $\begin{array}{c}60.7 \\
(\max =65.0-\min =55.6 ; n=7)\end{array}$ & \\
\hline Dama clactoniana & Riano & MIS 9 & (Bonadonna, 1965) & 61.7 & 64 \\
\hline Dama dama & Modern & MIS 1 & (Di Stefano, 1994) & $\begin{array}{c}52.4 \\
(\max =54.4-\min =50.7 ; n=3)\end{array}$ & $\begin{array}{c}53.5 \\
(\max =57.8-\min =50.2 ; n=4)\end{array}$ \\
\hline
\end{tabular}

Tab. 1. Table of the averages of $\mathrm{M}^{2}$ and $\mathrm{M}_{2}$ of fallow deer from the Middle Pleistocene and modern.

Here, we present the body-mass estimation of two fallow deer, $D$. roberti and $D$. clactoniana, for the investigation of possible changes through the Middle Pleistocene as a response to climatic fluctuations and/ or possible evolutionary trend.

\section{Material and Methods}

The fossil material studied comes from Contrada Monticelli (Castellana Grotte, Bari) that is currently preserved at the Museum of Earth Sciences of the University of Bari. The material consists of four craniodental findings: 30685 , left jaw with $\mathrm{P}^{3}-\mathrm{M}^{3}$; 3066, right hemimandible with $\mathrm{P}_{3}-\mathrm{M}_{3}$, left with $\mathrm{P}_{4}$ $\mathrm{M}_{3}$ and right maxillary with $\mathrm{M}^{1}-\mathrm{M}^{2}$ (catalog number 30660); 30674, left hemimandible with $\mathrm{P}_{4}-\mathrm{M}_{3} ; 30659$, splancnocranium with mandible. The material of $D$. clactoniana from Melpignano and San Sidero, stored at PaleoFactory Laboratory, Department of Earth Science, Sapienza (University of Rome) is taken into account for comparison. We built our dataset, collecting the measurements of $\mathrm{M}^{2}$ and $\mathrm{M}_{2}$ of the fallow deer from the Middle Pleistocene of Europe. The data of the extant fallow deer (Dama dama) were obtained by Di Stefano (1994). Body-mass estimation was calculated following Janis (1990). According to Janis (1990), the estimation of the body-mass in Artiodactyla based on both upper and lower first molar and third molar is unreliable, underestimating and overestimating the weight respectively. Therefore, the estimation of the body-mass was performed on the values of $\mathrm{M}^{2}$ and $\mathrm{M}_{2}$ (Tab. 1).

\section{Results ANd Discussions}

A series of well-known fossil samples has been selected, all having a more or less abundant presence of fallow deer and covering a time span ranging from 700,000 to 250,000 years ago (Fig. 1). The most ancient samples, coming from Pakefield, West Runton, Soleilhac, Isernia La Pineta, Contrada Monticelli and Valdemino, belong to Dama roberti (or Dama cf. roberti), the deer species recognized during the early Middle Pleistocene. The body-mass estimated for the samples coming from these sites shows how Pakefield (MIS 17), the oldest, records measure larger than those from the other localities (Tab. 1). Whilst, a slight decline in the average dimension is observed both in Soleilhac (MIS 17-15) and West Runton (MIS 17-15) (Tab. 1). In particular, the values from Soleilhac fall in the variability of the extant fallow deer (Tab. 1). Contrada Monticelli (MIS 15) presents a huge variability of the body-mass estimation, with the largest value in the $\mathrm{M}^{2}$ and the smallest in $\mathrm{M}_{2}$ (Tab. 1). The samples from Isernia La Pineta (MIS 15) and Valdemino (MIS 14) show similar values, both larger than those from Soleilhac and West Runton. The samples coming from Valdarno-Notarchirico, Fontana Ranuccio, Riano, San Sidero and Melpignano, belong instead to Dama clactoniana. The body-mass estimated for these localities is quite constant, except for the larger value of $\mathrm{M}_{2}$ from Riano (MIS 11) and the lower value of $\mathrm{M}_{2}$ from Venosa-Notarchirico (MIS 12) (Tab. 1). The overall values of $D$. clactoniana are similar to those of Dama cf roberti from Isernia La Pineta and D. roberti from Valdemino (Tab. 1). Finally, both fossil fallow deer, $D$. roberti and $D$. clactoniana, are larger than the extant D. dama (Tab. 1).

According to Mazza \& Bertini (2013), the large mammals are significantly affected by the severe 


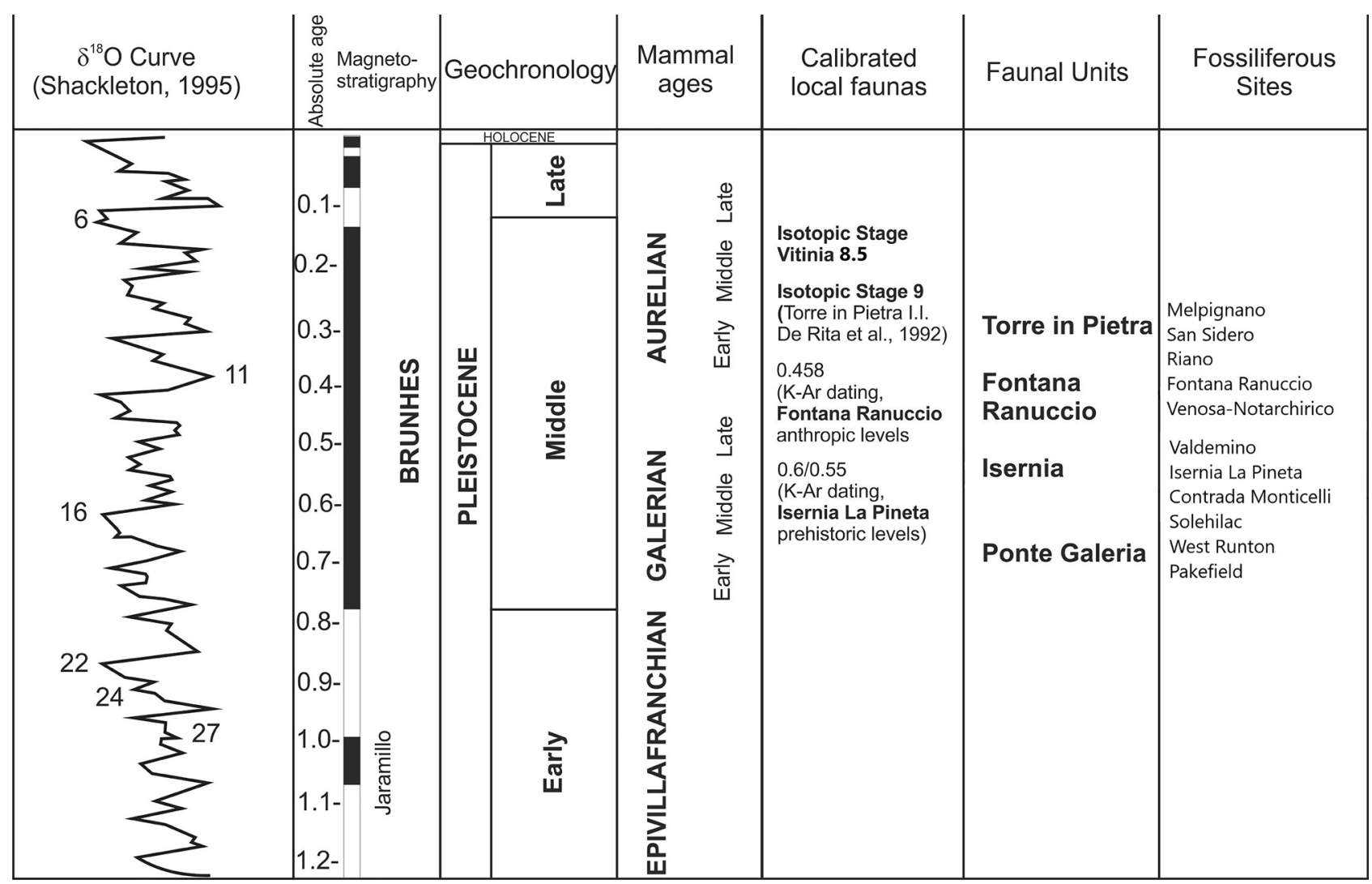

Fig. 1. Biocronological scheme of the fossiliferous sites discussed in the text.

Pleistocene climatic fluctuations. Food stress derived from climate change can affect the size of herbivores such as reindeer by placing a limit on the size (Weinstock, 1997), especially where there is a shift from a condition of greater abundance of vegetation, typical of interglacial times, to a condition of relative scarcity, typical of glacial periods. In the case of omnivores, as in wild boars, and carnivores, as in wolves and foxes, an increase in size has been instead found related to a decrease in temperatures (Davis, 1981). In the case of the sample examined for this study, it is possible to observe that there is no substantial difference in size between the two Pleistocene species $D$. roberti and $D$. clactoniana; vice versa, they are larger on average than the extant species $D$. dama. The largest dimensions both in $D$. roberti and $D$. clactoniana have been found in the sites respectively of Pakefield and Riano, both correlated to during interglacial phases. On the contrary, from West Runton and Soleilhac, the reduction of the body-mass could suggest a decrease in size probably linked to cold climatic conditions. In Italian record, no differences can be detected among the samples of $D$. roberti, since the values for the material from interglacial and glacial stages are closer. In the considered samples of $D$. clactoniana, the body mass is quite constant throughout the late Middle Pleistocene.
The large size during interglacial stages in fossil fallow deer was also reported by Van der Made et al. (2014), which detected similar patterns in Megaloceros giganteus Blumenbach, 1799 and C. elaphus. In this scenario, the fluctuation of body mass in Middle Pleistocene fallow deer of Europe contrasts with what generally supposed on size variation as response to climate. A possible interpretation of this body-mass fluctuation could be the result of a mix between ecological factors and climate. In fact, the fallow deer inhabit a wide range of habitats, including forest, scrubland and grassland, prefers temperate climatic conditions. Despite the high competition during the interglacials, the paleoenvironmental framework was favorable for the diffusion of this taxon, with higher quality and quantity of food resources. The increase of food supply could result in the development of a larger body size. Furthermore, the large size in herbivore taxa from Europe in glacial stages was recognized only during the Last Glacial (MIS 2, Late Pleistocene), for instance in C. elaphus (Steele, 2002; Van der Made et al., 2014; Di Stefano et al., 2015;). By the start of Middle Pleistocene, the Last Glacial was the more intense glacial episode, with a strong impact on mammal assemblage. Probably, rather than a high quality and quantity of food resources, the large size during the Last Glacial recognized in 
cervid fossil sample of Europe could be a consequence of a reduction of the demographic pressure in relation to a higher mortality rate (Weinstock, 1997).

\section{Conclusion}

The estimation of the cervid Dama body-mass in Middle Pleistocene is here performed for the first time. No difference can be detected between the Middle Pleistocene taxa, $D$. roberti and D. clactoniana, whereas these fossil species are larger than extant $D$. dama. These results suggest that the body-mass in the specimens from interglacial stages was larger than those from glacial ones. The size fluctuation in Middle Pleistocene fallow deer was related to favorable paleoenvironmental condition, with high quality and quantity of food resources, that in turn were controlled by climatic conditions.

\section{REFERENCES}

Blumenbach J. F. (1799). Abbildugen naturhistorischer Gegenstände. Gottingen 4: 31-40, pp.1-22, pl. 31-40.

Breda M. (2015). The early Middle Pleistocene fallow deer Dama roberti new insight on species. Geological Journal, 50: 257-270.

Breda M. \& Lister A. (2013). Dama roberti, a new species of deer from the early Middle Pleistocene of Europe, and the origins of modern fallow deer. Quaternary Science Reviews, 69: 155-167.

Breda M., Peretto C. \& Thun-Hohenstein U. (2015). The deer from the early Middle Pleistocene site of Isernia la Pineta (Molise, Italy): revised identifications and new remains from the last 15 years of excavation. Geological Journal, 50: 290-305.

Brooke V. (1875). On the Existence of the Fallow Deer in England During Pleistocene Times . Nature 11: 210-211.

Cassoli F., Di Stefano G. \& Tagliacozzo A. (1999). I Vertebrati dei livelli superiori (Alfa ed A) della serie stratigrafica di Notarchirico. In: Piperno, M. (Ed.), Notarchirico: Un sito del Pleistocene medio iniziale nel bacino di Venosa, Edizioni Osanna, Venosa, Italia, pp. 361-438.

Davis S. J. M. (1981). The effect of temperature change and domesticationon the body size of late Pleistocene to Holocene mammals of Israel. Paleobiology 7: 101-114.

Di Stefano G. (1994). PhD Thesis. Il daino pleistocenico dell'Eurasia; 270 pp.

Di Stefano G., Pandolfi L., Petronio C. \& Salari L. (2015). Considerations on the morphometryand the occurrence of Cervus elaphus (Mammalia, Cervidae) from the Late Pleistocene of the Italian Peninsula. Rivista Italiana di Paleontologia e Stratigrafia, 121: 1-18.

Geist V. (1971). Mountain Sheep: A Study in Behavior and Evolution. University of Chicago Press, Chicago. 383 pp.

Geist V. (1987). Bergmann's rule is invalid. Canadian Journal of Zoology, 65: 1035-1038.

Guthrie R. D. (1984). Mosaics, allelochemics, and nutrients: an ecological theory of late Pleistocene megafaunal extinctions. In Martin, P. S. \& Klein, R. G. (eds.): Quaternary Extinctions, a Prehistoric Revolution, 259-298.
University of Arizona Press, Tucson.

Janis C. M. (1990). Correlation of cranial and dental variables with body size in ungulates and macropodoids. In Damuth, J. \& Mac-Fadden, B. J. (eds.): Body Size in Mammalian Paleobiology: Estimation and Biological Implications, 255-299. Cambridge University Press, Cambridge.

Lacombat F. (2005). Les rhinocéros fossiles des sites préhistoriques de l'Europe méditerranéenne et du Massif central. Paléontologie et implications biochronologiques - BAR International Series, 1419: 175 pp.

Lindstedt S. L. \& Boyce M. S. (1985). Seasonality, fasting endurance, and body size in mammals. American Nature, 125: 873-878.

Linnaeus C. (1758). Systema naturae per regna tria naturae, secundum Classes, Ordines, Genera, Species, cum characteribus, differentiis, synonymis, locis. Tomus I. 824 pp. Laurentius Salvius, Stockholm.

Lister A.M., Parfitt S.A., Owen F.J., Collinge S.E. \& Breda M. (2010). Metric analysis of ungulate mammals from the early Middle Pleistocene of Britain, in relation to taxonomy and biostratigraphy. II: Cervidae, Equidae and Suidae. Quaternary International 228: 157-179.

Marra F., Petronio C., Ceruleo P., Di Stefano G., Florindo F., Gatta M., La Rosa M., Rolfo M. F. \& Salari L. (2018). The archaeological ensemble from Campoverde (Agro Pontino, central Italy): new constraints on the Last Interglacial sea level markers. Scientific Report 8, 17837.

Masseti M. \& Mertzanidou D. (2008). Dama dama. The IUCN Red List of Threatened Species 2008: e.T42188A10656554.

Mazza P.P.A. \& Bertini A. (2013). Were Pleistocene hippopotamuses exposed to climate-driven body size changes? Boreas, 42: 194-209.

Mecozzi B. \& Bartolini Lucenti S. (2018). The Late Pleistocene Canis lupus (Canidae, Mammalia) from Avetrana (Apulia, Italy): reappraisal and new insights on the European glacial wolves. Italian Journal of Geosciences, 137: 138-150.

Mecozzi B., Iurino D. A., Berté D. F. \& Sardella R. (2017) - Canis mosbachensis (Canidae, Mammalia) from the Middle Pleistocene of Contrada Monticelli (Putignano, Apulia, southern Italy). Bollettino Società Paleontologica Italiana, 56: 72.

Mecozzi B., Bellucci L., Giustini F., Iurino D., Mazzini I. \& Sardella R. (2019). Large mammal fauna from the late Middle Pleistocene sites of Melpignano and San Sidero (Lecce, Southern Italy). Paleodays 2019. La Società Paleontologica Italiana a Benevento e Pietraroja. Parte 1: Volume dei riassunti della XIX Riunione annuale SPI (Società Paleontologica Italiana). Abstract volume: 24.

Strani F., Demiguel D., Bona F., Sardella R., Biddittu I., Bruni L., De Castro A., Guadagnoli F. \& Bellucci L. (2018). Ungulate dietary adaptations and palaeoecology of the Middle Pleistocene site of Fontana Ranuccio (Anagni, Central Italy). Palaeogeography, Palaeoclimatology, Palaeoecology 496: 238-247.

Steele, T. E. (2002). Red deer: their ecology and how they were hunted by Late Pleistocene hominids in western Europe (Doctoral dissertation, Stanford University).

Stefanelli D., Mecozzi B., Marino M., Girone A., Sardella R., Breda M., Francescangeli R. \& Montenegro V. (2019) - Contrada Monticelli (Castellana Grotte, southern 
Italy): the southernmost occurrence of the early Middle Pleistocene Dama cf. roberti (Cervidae, Mammalia). Paleodays 2019. La Società Paleontologica Italiana a Benevento e Pietraroja. Parte 1: Volume dei riassunti della XIX Riunione annuale SPI (Società Paleontologica Italiana). Abstract volume: 43

Stuart A.J. \& Lister A. (2010). Extinction chronology of the cave lion Panthera spelaea. Quaternary Science Reviews, 30 (17-18):, 2329-2340.

Van Asperen E.N. (2010). Ecomorphology and migratory behaviour of Late Middle Pleistocene horses in northwest Europe. Palaeogeography, palaeoclimatology, palaeoecology, 297: 584-596.
Van Asperen E.N., Stefaniak K., Proskurnyak I., \& Ridush B. (2012). Equids from Emine-Bair-Khosar Cave (Crimea, Ukraine): co-occurrence of the stenonid Equus hydruntinus and the caballoid E. ferus latipes based on skull and postcranial remains. Palaeontologia Electronica 15.1.5A: $1-28$

Van der Made J., Stefaniak K., \& Marciszak A. (2014). The Polish fossil record of the wolf Canis and the deer Alces, Capreolus, Megaloceros, Dama and Cervus in an evolutionary perspective. Quaternary international, 326: 406-430.

Weinstock J. (1997). The relationship between body size and environment the case of Late Pleistocene reindeer (Rangifer tarandus). Archeofauna 6: 123-135. 
